\title{
Calibration and validation of FAO-AquaCrop model to estimate the total biomass and yacon root yield
}

\author{
Ramon Amaro de Sales ${ }^{1 *}$, Alexandre Cândido Xavier², Evandro Chaves de Oliveira ${ }^{3}$, \\ Fábio Luiz de Oliveira², Diego Mathias Natal da Silva ${ }^{4}$, Sávio da Silva Berilli ${ }^{3}$ \\ (1. Departament of Plant Science, Federal University of Viçosa, Minas Gerais, Brazil; \\ 2. Center of Agrarian Sciences and Engineering, Federal University of Espirito Santo, Espírito Santo, Brazil; \\ 3. Federal Institute of Education, Science and Technology of Espírito Santo - Campus Itapina, Espírito Santo, Brazil; \\ 4. Federal Institute of Education, Science and Technology of Southeast Minas Gerais - Campus Manhuaçu, Minas Gerais, Brazil)
}

\begin{abstract}
Due to the current water scarcity in the world, it is extremely important to improve the use of this natural and exhaustible resource in agriculture, by contributing to increase agricultural production and sustainability. Several models of crop growth simulation were developed to predict the edaphoclimatic effects on crop yield. These models are calibrated and validated for a given region using the data generated from field experiments. Therefore, the objective of this study was to calibrate and validate the FAO AquaCrop model for yacon (Smallanthus sonchifolius) crop in a tropical climate. The experiment was conducted in an experimental area located in the municipality of Ibatiba, state of Espírito Santo (Brazil) during the years of 2013 and 2014. The calibration was done using the Autumn planting and validation with the Winter and Spring plantings. For the statistical analysis, the coefficient of determination, Willmott concordance index, bias for the systematic error, root mean square error and the mean absolute error to test the model performance were used. In general, the FAO AquaCrop model predicted the root yield, total biomass and harvest index with acceptable accuracy, and with deviations of less than $6 \%$ for total and root biomass. Late planting of yacon showed a reduction in yield as well as total biomass.
\end{abstract}

Keywords: Smallanthus sonchifolius, root yield simulation, modelling, agrometeorology

DOI: $10.25165 /$ j.ijabe.20201303.5012

Citation: de Sales R A, Xavier A C, de Oliveira E C, de Oliveira F L, da Silva D M N, Berilli S S. Calibration and validation of FAO-AquaCrop model to estimate the total biomass and yacon root yield. Int J Agric \& Biol Eng, 2020; 13(3): $123-128$.

\section{Introduction}

The management of water resources demands detailed studies, since fresh water is an indispensable and exhaustible natural resource, with a fundamental role in the development of living beings ${ }^{[1,2]}$. Therefore, many agrometeorological models have been developed to assist in water resources planning and decision making, and they are used by several researchers in different parts of the world.

Among them, we can mention CropWat ${ }^{[3]}$, DSSAT ${ }^{[4]}$, AquaCrop ${ }^{[5-7]}$, CropSyst ${ }^{[8]}$. In addition, they are widely used for the purposes of agroclimatic zoning and irrigation management,

Received date: 2019-03-03 Accepted date: 2020-03-17

Biographies: Ramon Amaro de Sales, PhD, Plant Sciences, research interests: agrometeorology and plant production, Email: ramonamarodesales@gmail.com; Alexandre Cândido Xavier, $\mathrm{PhD}$, Irrigation and Drainage, research interests: remote sensing and geoprocessing, Email: alexandre.candido.xavier.ufes@, gmail.com; Evandro Chaves de Oliveira, $\mathrm{PhD}$, Applied Meteorology, research interests: agrometeorological modeling and water resources, Email: echoliveira@gmail.com; Fábio Luiz de Oliveira, PhD, Plant Sciences, research interests: organic management and olericulture, Email: fabiocapi@yahoo.com.br; Diego Mathias Natal da Silva, PhD, Plant Production, research interests: organic management and soil and water management and conservation, Email: diegoufvjm@yahoo.com.br; Sávio da Silva Berilli, PhD, research interests: soil fertility and seedling production, Email: berilli@ gmail.com.

*Corresponding author: Ramon Amaro de Sales, PhD, Plant Sciences, research interests: agrometeorology and plant production. Mailing address: Federal University of Viçosa, CEP: 36570-900, Minas Gerais, Brazil. Tel: +55 27 99700-0143, Email: ramonamarodesales@gmail.com. since the correct management and use to add or supplement the water demand of the crop can result in higher yields ${ }^{[9,10]}$. Thus, the use of crop growth models is crucial for the optimization of agricultural practices and, even more importantly, for modeling plant cover variations on an annual scale ${ }^{[11]}$.

The AquaCrop model, developed by FAO, provides a good balance between robustness, simplicity and precision of the output, and it can be used for a wide variety of crops ${ }^{[12,13]}$ using few input parameters. Although they are found in the literature on potato studies $^{[14-16]}$, there is still limited information on modeling with yacon.

Yacon (Smallanthus sonchifolius) is a tuberous root-producing plant from the Andes that stores carbohydrates in the form of fructooligosaccharides. This is one of the reasons because yacon is considered a functional food with high nutraceutical potential ${ }^{[17]}$.

The water demand of the crop has been pointed out as the most determinant factor for the production of tuberous roots ${ }^{[18]}$. Therefore, the use of agrometeorological models, aiming to assist in the planning of water resources and the decision making for the fulfillment of crop water demand, can result in higher yields. However, prior to the direct use of any model, calibration activity is fundamental to meet specific characteristics of each crop or variety and efficiently simulate its growth and development in particular pedo-climatic conditions.

Validation is the second fundamental activity before model applicative use; it is performed through model tests calibrated at other sites and/or seasons in order to test the model's ability to simulate climatic fluctuations. Thus, the objective of this study 
was to calibrate and validate the AquaCrop model for yacon crops in a tropical climate.

\section{Materials and methods}

\subsection{Climatic characteristics and location of the experiment}

The field experiments were installed and conducted in an agricultural area, in the municipality of Ibatiba $\left(20^{\circ} 17^{\prime} \mathrm{S}, 41^{\circ} 37^{\prime} \mathrm{W}\right.$, $837 \mathrm{~m}$ in altitude) located in the state of Espírito Santo, Brazil (Figure 1), in a randomized block design, with four replicates.

The treatments were constituted by three planting seasons of yacon in 2013: Autumn (April 20), Winter (July 20) and Spring (September 20). For meteorological monitoring, a meteorological station belonging to the Capixaba Institute for Research, Technical Assistance and Rural Extension - INCAPER located near (10654 m) the experimental area was used. The behavior of the maximum and minimum air temperatures, as well as the precipitation, occurred along the crop cycle in their respective plantations, which can be observed in Figure 2 .

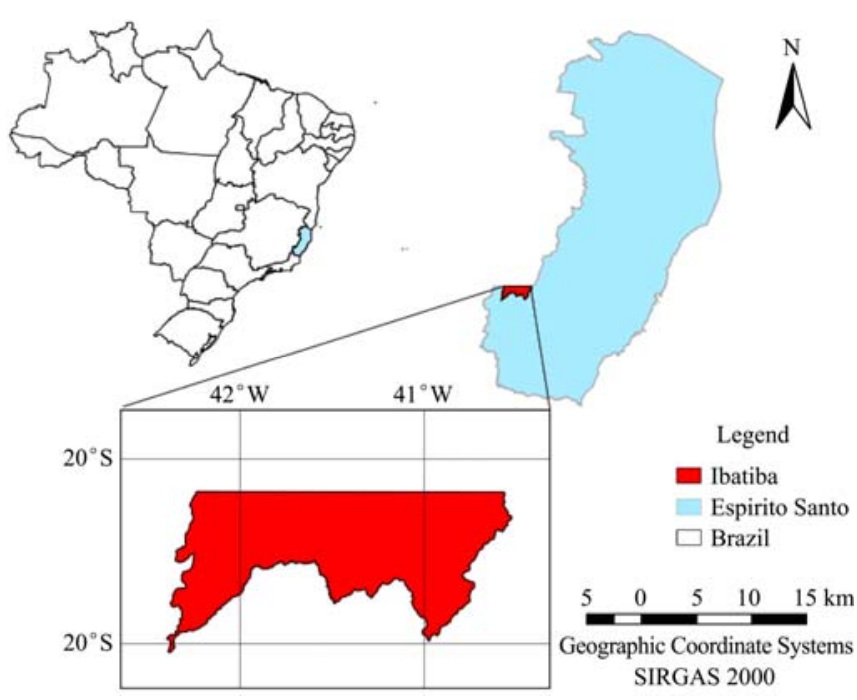

Figure 1 Geographic location of the state of Espírito Santo, in Brazil, with emphasis on the municipality of Ibatiba

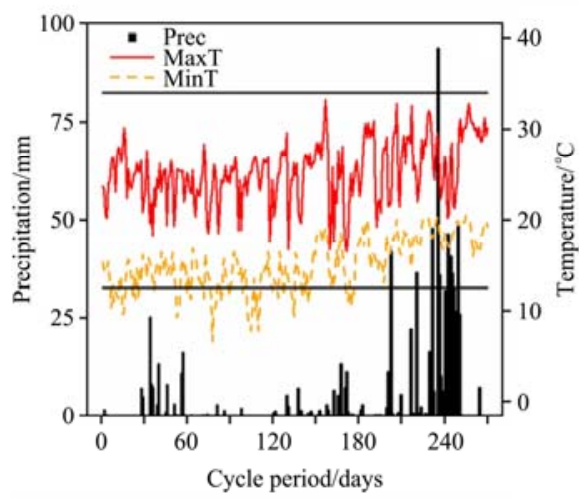

a. Autumn

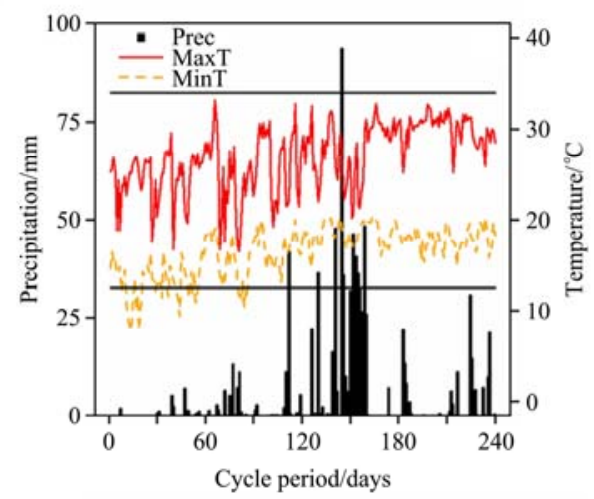

b. Winter

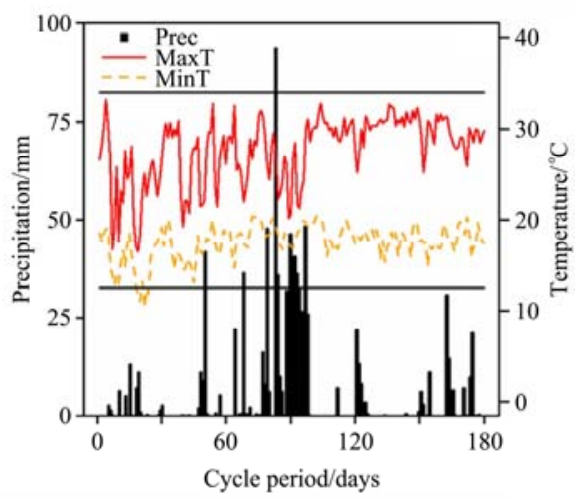

c. Spring

Figure 2 Maximum and minimum air temperatures and precipitation during the three planting seasons: Autumn, Winter and Spring. Bottom and upper continuous lines refer to lower (Tb) and upper (TB) basal temperatures, respectively

Using the daily data of maximum and minimum air temperatures, potential evapotranspiration was calculated by Thornthwaite method ${ }^{[19]}$ on a monthly scale, since it uses only average air temperature data as input data, it is inserted into the AquaCrop model, according to Equations (1)-(6).

$$
\begin{gathered}
\operatorname{ETP}=16 \times\left(10 \times \frac{T i}{I}\right)^{a} \quad 0^{\circ} \mathrm{C} \leq T_{i} \leq 26^{\circ} \mathrm{C} \\
\text { ETo }=-415.85+32.24 \times T_{i}-0.43 \times T_{i}^{2} \quad T_{i}>26^{\circ} \mathrm{C}
\end{gathered}
$$

where, ETP is the potential evapotranspiration, $\mathrm{mm} / \mathrm{mon} ; T_{i}$ is the monthly mean air temperature, ${ }^{\circ} \mathrm{C}$.

$I$ is the thermal index imposed by the local climate regime, calculated by:

$$
\begin{gathered}
I=\sum_{n=1}^{12}\left(0.2 \times T_{i}\right)^{1.514} \\
a=6.75 \times 10^{-7} \times I^{3}-7.71 \times 10^{-5} \times I^{2}+1.7912 \times 10^{-2} \times I+0.49239
\end{gathered}
$$

where, suffix $i$ represents the month of the year $(i=1,2, \ldots, 12)$.

After obtaining the ETP value, the correction was performed according to the real number of days and the photoperiod of the month by means of Equations (5) and (6).

$$
\begin{gathered}
\mathrm{ETP}=\mathrm{ETP} \times \mathrm{Cor} \\
\mathrm{Cor}=\left(\frac{N D}{30}\right) \times\left(\frac{N}{12}\right)
\end{gathered}
$$

where, $N D$ is the number of days in the month in question, and $N$ is the average photoperiod of that month.

\subsection{Cultivation practices}

The soil was prepared by plowing at $30 \mathrm{~cm}$ depth followed by harrowing. The planting method was manual, performed in grooves using rhizophores of approximately $35 \mathrm{~g}$ at a depth of $10 \mathrm{~cm}$, obeying the desired spacing. $180 \mathrm{~g}$ of tanned bovine manure per plant were placed. Bovine manure contained the following nutrients: $14.21 \mathrm{~g} / \mathrm{kg} \mathrm{N} ; 4.75 \mathrm{~g} / \mathrm{kg} \mathrm{P} ; 5.28 \mathrm{~g} / \mathrm{kg} \mathrm{K}$; $4.29 \mathrm{~g} / \mathrm{kg} \mathrm{Ca}$ and $1.92 \mathrm{~g} / \mathrm{kg} \mathrm{Mg}$. During the cultivation cycle, conventional sprinkler irrigation was used, maintaining the crop always in the field capacity. The local soil was classified as red-yellow latosol

The local soil was classified as medium texture Red-Yellow Latosol $^{[20]}$, and the sample was submitted to the CCAE/UFES Soil Laboratory for chemical and physical analysis. A sample collected from 0-20 cm, was analyzed and showed the following characteristics. $\mathrm{pH}$ (water): 6.20; Phosphorus Mehlich 1: $53.99 \mathrm{mg} / \mathrm{dm}^{3}$; Potassium: $80.00 \mathrm{mg} / \mathrm{dm}^{3}$; Calcium: $2.12 \mathrm{cmolc} / \mathrm{dm}^{3}$; Magnesium: $0.87 \mathrm{cmolc} / \mathrm{dm}^{3}$; Aluminium: $0.0 \mathrm{cmolc} / \mathrm{dm}^{3}$; Sum of bases: $3.24 \mathrm{cmolc} / \mathrm{dm}^{3}$; CTC effective: $3.24 \mathrm{cmolc} / \mathrm{dm}^{3}$; Total organic carbon: $1.83 \%$; Total nitrogen: $0.15 \%$.

In order to estimate the soil variables, pedotransfer functions (PTF) were used, thus obtaining the saturation humidity, field capacity, permanent wilting point and saturated hydraulic conductivity required for simulation by the AquaCrop model. Using the methodology proposed by Tomasella ${ }^{[21]}$ were derived 
from the soil variables of the present study region were, and presented in Table 1.

Table 1 Soil properties used as an input in the AquaCrop model for yacon simulation in Ibatiba-ES

\begin{tabular}{cccccc}
\hline Layers & Depth $/ \mathrm{m}$ & $\mathrm{PWP} / \%$ & $\mathrm{FC} / \%$ & Saturation $/ \%$ & $\mathrm{~K}_{\text {sat }} / \mathrm{mm} \mathrm{d}^{-1}$ \\
\hline 1 & $0.00-0.20$ & 11.0 & 26 & 53 & 280.8 \\
2 & $0.20-0-50$ & 11.0 & 26 & 53 & 280.0 \\
\hline
\end{tabular}

Note: PWP: permanent wilting point; FC: field capacity; Ksat: saturation and saturated hydraulic conductivity.

The experimental unit consisted of five planting lines of $8 \mathrm{~m}$, spaced $1.0 \mathrm{~m}$ between rows and $0.5 \mathrm{~m}$ between plants, totaling 16 yacon plants per planting line, and they were evaluated every $30 \mathrm{~d}$ after the emergence. Every $30 \mathrm{~d}$ after the emergency, two plants per experimental unit, randomly chosen within the central lines, except for the borders, were collected for evaluation. The total dry mass and root mass data were obtained in a forced air circulation oven at $(70 \pm 5)^{\circ} \mathrm{C}$ until constant mass, and they were converted to biomass by land area, considering the plant density of each plot ( 2 plants $/ \mathrm{m}^{2}$ ).

\subsection{Brief description of the AquaCrop model}

The model is based on the soil-plant-atmosphere components of the soil, atmosphere, crop characteristics and crop management ${ }^{[12,13]}$. The model calculates the daily water balance and separates its evapotranspiration in evaporation and transpiration, and the transpiration of the crop is linked to the canopy cover (proportional to the extension of the soil cover), while evaporation is proportional to the area of uncovered soil ${ }^{[22]}$.

AquaCrop simulates the daily production of biomass and the yield of the crops according to the water demand of the crop and the agronomic management ${ }^{[23]}$. The details of the simulated processes are provided in a set of three articles ${ }^{[12,13,24]}$, which were published by Irrigation and Drainage No. 66 'Results of crop yield to water' and the reference manual ${ }^{[25]}$. Figure 3 shows the interface of the AquaCrop version 6.0 model used.

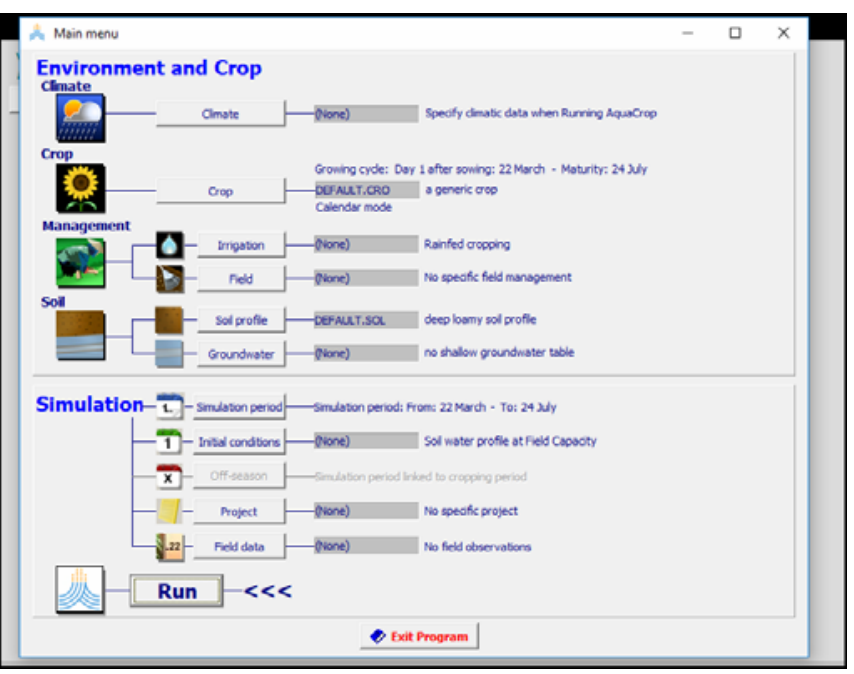

Figure 3 Window that illustrates the database system for the simulation of AquaCrop model

\subsection{Adjustment of crop parameters}

The development of the canopy was measured in terms of growth phases, through leaf area, total biomass and root biomass on monthly basis after the emergence of $80 \%$ of the plants. The yacon variables used for the calibration of the AquaCrop model are presented in Table 2. The same values of this set of variables were used to evaluate the performance and robustness of AquaCrop in the Winter and Spring plantings.
Table 2 Selected crop variables and values for AquaCrop calibration for yacon

\begin{tabular}{|c|c|}
\hline Variables & Value \\
\hline Base temperature $/{ }^{\circ} \mathrm{C}$ & 12.5 \\
\hline Upper temperature $/{ }^{\circ} \mathrm{C}$ & 34.0 \\
\hline Relative weed coverage $/ \%$ & 5.0 \\
\hline Canopy growth coefficient $-\mathrm{CGC} / \% \cdot \mathrm{d}^{-1}$ & 8.5 \\
\hline Canopy decline coefficient $\mathrm{CDC} / \% \cdot \mathrm{d}^{-1}$ & 1.08 \\
\hline Soil water depletion threshold for canopy expansion-Upper threshold & 25.0 \\
\hline Soil water depletion threshold for canopy expansion-Upper threshold & 55.0 \\
\hline Shape factor for Water stress coefficient for canopy expansion & 3.0 \\
\hline Soil depletion factor for stomatal control & 0.50 \\
\hline Shape factor for Water stress coefficient for stomatal control & 3.0 \\
\hline Soil water depletion factor for early canopy senescence & 0.55 \\
\hline Cold stress $/{ }^{\circ} \mathrm{C}$ & 5.0 \\
\hline Standard water production $\mathrm{WP} * / \mathrm{g} \cdot \mathrm{m}^{-2}$ & 15.0 \\
\hline Harvest index/\% & 56.0 \\
\hline Plant density/plants $\cdot \mathrm{hm}^{-2}$ & 20000.0 \\
\hline CCo initial coverage cover $/ \%$ & 0.10 \\
\hline Maximum canopy growth/\% & 83.0 \\
\hline Time to maximum canopy coverage (GD) & 1135.0 \\
\hline Time for senescence (GD) & 1767.0 \\
\hline Time to maturity (GD) & 1862.0 \\
\hline Maximum effective rooting depth $/ \mathrm{m}$ & 0.35 \\
\hline
\end{tabular}

\subsection{Parameterization and validation of the model}

To determine the performance of the adjustment in the model in the parameterization and validation, the observed values of total dry biomass, root yield and harvest index observed in the field were compared with those simulated by the model. The results are presented and discussed by planting seasons (Autumn, Winter and Spring) in which simulated and observed values of accumulated biomass, root yield and harvest index were compared.

The calibration of the AquaCrop was done through an iterative process that introduced the values that best simulated the primary growth variables of the crop, such as canopy cover, harvest index, total dry matter content and root dry matter content, which occurred in Autumn. The validation of AquaCrop was carried out by plantations in the Winter and Spring. In addition, after the parameters calibrated for the Autumn crop, the conservative and non-conservative parameters, which depend on the cultivar of the crop, were considered constant.

The statistical indexes used were: linear regression analysis and determination coefficient $R^{2}$, Willmott's concordance index $d^{[26]}$, the bias for the systematic error, root mean square error (RMSE) and mean absolute error (MAE) (Equations (7)-(11)).

$$
\begin{gathered}
R^{2}=\left[\frac{\sum_{i=1}^{n}\left(\left|E_{i}-\bar{E}\right|\right)\left(\left|O_{i}-\bar{O}\right|\right)}{\sqrt{\sum_{i=1}^{n}\left(E_{i}-\bar{E}\right)^{2}} \sqrt{\sum_{i=1}^{n}\left(O_{i}-\bar{O}\right)^{2}}}\right]^{2} \\
d=1-\frac{\sum_{i}^{n}\left(O_{i}-E_{i}\right)^{2}}{\sum_{i=1}^{n}\left(\left|E_{i}-\bar{O}\right|+\left|O_{i}-\bar{O}\right|\right)^{2}} \\
\operatorname{BIAS}=\frac{\sum_{i=1}^{n}\left(O_{i}-E_{i}\right)}{N} \\
\text { RMSE }=\left[\frac{\sum_{i=1}^{n}\left(E_{i}-O_{i}\right)^{2}}{N}\right]^{1 / 2}
\end{gathered}
$$




$$
\text { MAE }=\frac{\sum_{i=1}^{n}\left|O_{i}-E_{i}\right|}{N}
$$

where, $O_{i}, E_{i}, \bar{O}$ and $\bar{E}$ represent the observed values in the field, the values simulated by AquaCrop, and the average of the values observed and simulated by AquaCrop; $N$ is the number of observations. The entire statistical procedure was performed with the aid of the R program ${ }^{[27]}$.

\section{Results and discussion}

In Table 3, the deviations obtained between the values observed and simulated by the AquaCrop model for the three planting seasons in Ibatiba, Espirito Santo, that were done at the end of the experiment, are presented. It is observed that the value calibrated in the Autumn showed a deviation of $-8.6 \%$ for the HI, while the Winter and Spring plantings, times used to validate the model showed $7.6 \%$ and $-1.4 \%$ of deviation, respectively.

The values of harvest index (HI) obtained in the field tests were similar to those obtained by other authors ${ }^{[25,28,29]}$ for common potato (Solanum tuberosum). Values above $7 \%$ in the harvest index for Autumn and Winter plantings are due to climate changes, such as the temperature, since in both dates, there were higher frequencies of minimum temperatures below the lower basal temperature. As observed by Hanks ${ }^{[30]}$ and Struik and Ewing ${ }^{[31]}$, $\mathrm{HI}$ is sensitive to major changes in climate, in which temperature and photoperiod are the main climatic factors affecting the rate of biomass accumulation, as well as partitions between the leaves, stems, roots and tubers.

Table 3 Percentage deviation for harvest index, total biomass and simulated root yield observed for yacon crop at the end of the experiment, for the three planting seasons, in the region of Ibatiba, Espirito Santo, Brazil, 2013

\begin{tabular}{|c|c|c|c|c|c|c|c|c|c|}
\hline \multirow{2}{*}{ Planting } & \multicolumn{3}{|c|}{$\mathrm{HI}$} & \multicolumn{3}{|c|}{ Total Biomass } & \multicolumn{3}{|c|}{ Root Yield } \\
\hline & Obs & Sim & Deviation $/ \%$ & Obs $/ \mathrm{t} \cdot \mathrm{hm}^{-2}$ & $\mathrm{Sim} / \mathrm{t} \cdot \mathrm{hm}^{-2}$ & Deviation/\% & Obs $/ \mathrm{t} \cdot \mathrm{hm}^{-2}$ & $\mathrm{Sim} / \mathrm{t} \cdot \mathrm{hm}^{-2}$ & Deviation/\% \\
\hline Autumn & 0.52 & 0.56 & -8.67 & 17.85 & 17.21 & 3.59 & 9.27 & 9.74 & -5.08 \\
\hline Winter & 0.61 & 0.56 & 7.65 & 13.54 & 14.04 & -3.97 & 8.30 & 7.97 & 3.92 \\
\hline Spring & 0.55 & 0.56 & -1.43 & 13.63 & 13.91 & 2.03 & 7.61 & 7.60 & 0.17 \\
\hline
\end{tabular}

Note: HI: Harvest Index; Obs, Sim refer to the values observed in the field and simulated by the AquaCrop model.

The total biomass value presented a deviation of $3.5 \%$ in the calibration (Autumn). The adjusted model presented satisfactory results in the respective Winter and Spring plantings, with deviations of $-3.9 \%$ and $2.0 \%$, respectively. It is noteworthy that the Autumn and Spring plantings presented final values of total biomass overestimating the simulated value, being corroborated by the bias (Table 4), with respective values of $0.64 \mathrm{t} / \mathrm{hm}^{2}$ and $0.21 \mathrm{t} / \mathrm{hm}^{2}$ for the Autumn and Spring plantings.

When the root yield was evaluated, a negative value is observed for the deviation obtained during Autumn planting. These values are corroborated by the systematic error (Table 4), presenting the value of $-0.47 \mathrm{t} / \mathrm{hm}^{2}$. However, the deviations obtained at the end of the experiment were good, with values below $6.0 \%$ for all simulations.

Table 4 Results of root mean square error (RMSE), absolute mean error (MAE) and Bias for yacon total biomass and root yield observed and simulated for three planting seasons in the Ibatiba region, ES, Brazil, 2013

\begin{tabular}{cccccccc}
\hline \multirow{2}{*}{ Planting } & \multicolumn{3}{c}{ Total Biomass $/ \mathrm{t} \cdot \mathrm{hm}^{-2}$} & & \multicolumn{3}{c}{ Root Yield $/ \mathrm{t} \cdot \mathrm{hm}^{-2}$} \\
\cline { 2 - 4 } \cline { 6 - 8 } & RMSE & Bias & MAE & & RMSE & Bias & MAE \\
\hline Autumn & 2.50 & 0.64 & 2.39 & & 1.22 & -0.47 & 0.74 \\
Winter & 1.30 & -0.53 & 1.18 & & 0.89 & 0.32 & 0.60 \\
Spring & 0.82 & 0.21 & 0.79 & & 0.71 & 0.01 & 0.59 \\
\hline
\end{tabular}

Although a larger number of days were observed with minimum temperature values below the lower basal temperature (Figure 2) in the Autumn and Winter plantings, the production of both had higher values than the Spring planting. This is due to the increase in the yacon cycle duration during these planting seasons (Autumn and Winter), since the average temperature during the whole cycle was lower than the Spring planting, resulting in an increase in the required days for the end of the cycle and, consequently, for the green leaf area ${ }^{[32]}$. The model was able to respond with precision to this increase in the root yield as a function of the increase in the duration of the crop cycle.
In Figure 4, the regression analysis for observed and simulated root yield during the cycle, as well as its coefficient of determination and concordance index at different planting times, is graphically observed. According to the regression analysis, the AquaCrop model overestimated the values of dry root biomass at all planting times, when comparing the entire data set along the cycle, with low dispersion of the data and presenting values of $R^{2}>$ 0.92 .

This shows that the simulation of the model explained more than $92 \%$ of the variability of the data observed in the field. In addition, there was high agreement among the data, with $d=0.98$ in all planting seasons. The good parameterization of the model is due to the availability of soil cover data, which enabled the model to have a good response to the total yacon biomass (Table 3). The transpiration rate of a crop was affected by the canopy cover and, consequently, the accumulation of biomass, thus, the correct simulation of this variable results in a better performance of AquaCrop ${ }^{[33]}$.

For the error analysis obtained in this experiment, the value of 2.5 and $2.4 \mathrm{t} / \mathrm{hm}^{2}$ for RMSE and MAE, respectively, for total biomass (Table 4) is observed in the calibration (Autumn) phase. However, for root yield, these errors are reduced to 1.2 and $0.74 \mathrm{t} / \mathrm{hm}^{2}$ for RMSE and MAE, respectively.

The validation of the model presented lower errors than after the calibration, with a value of $0.82 \mathrm{t} / \mathrm{hm}^{2}$ of total biomass (RMSE) and $0.71 \mathrm{t} / \mathrm{hm}^{2}$ of root yield for the Spring planting. These results are close to those found by Montoya ${ }^{[16]}$ for potato (Solanum sp.), which were irrigated maintaining $100 \%$ field capacity, with RMSE of $1.32 \mathrm{t} / \mathrm{hm}^{2}$. Although the metric statistics express the prediction error of the model, the differences between the RMSE and the MAE values are due to the increase in the penalty obtained by the RMSE error when there are larger differences between the observed and simulated values.

In general, the AquaCrop model presented good results to simulate the root yield in the region of Ibatiba, Espírito Santo, Brazil. By running the model under different planting time 
scenarios, it is possible to optimize the planting date of the yacon, making AquaCrop a promising tool for predicting yacon root yield cultivated out of season in Ibatiba, as well as to estimate the irrigation need.

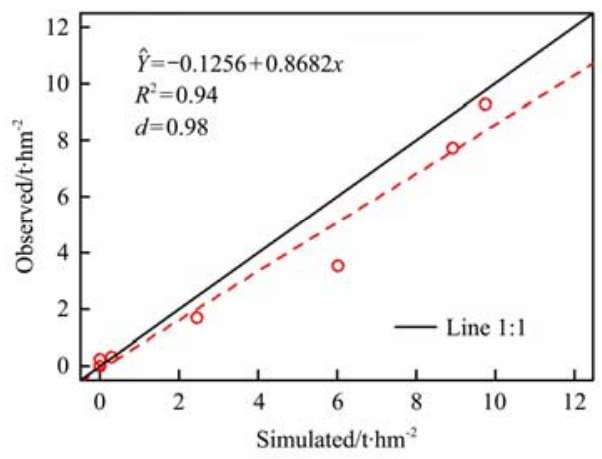

a. Autumn
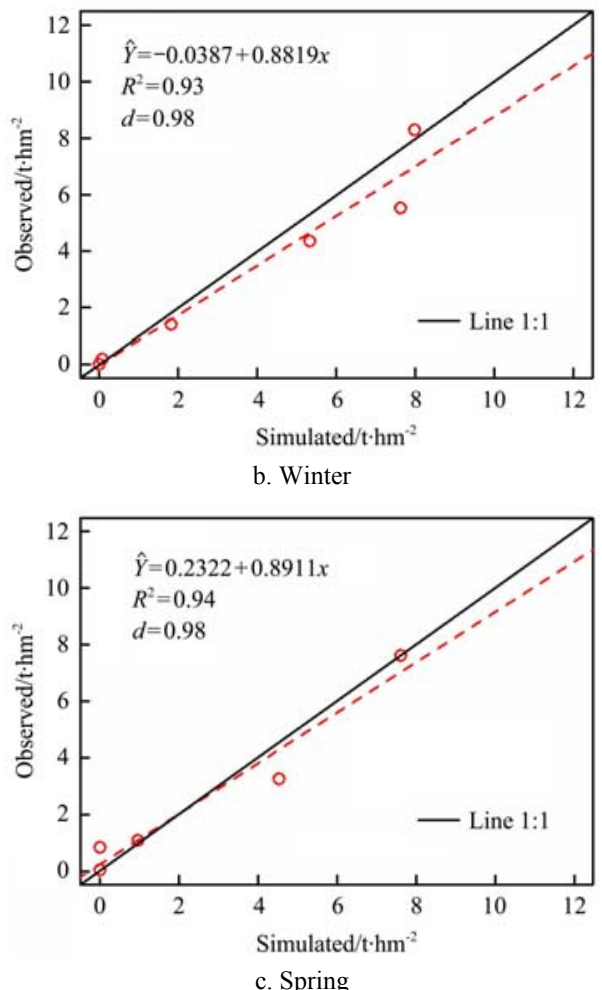

Figure 4 Relationship between the observed and simulated values for yacon root yield in Autumn (a), Winter (b) and Spring (c) crops during cycle

\section{Conclusions}

For the first time, the AquaCrop model was used to simulate yacon total biomass and root yield. AquaCrop version 6.0 adequately simulated the harvest index as well as total biomass and yacon root yield at different planting times, with deviations below $6 \%$ for total and root biomass.

The model can be used to mitigate the effects of climate change, evaluating in advance the optimal planting time.

AquaCrop can be used to model yacon production as well as strategic irrigation planning and for agroclimatic zoning.

\section{Acknowledgements}

The authors thank Capes, for the master's scholarship, CNPq, for the researcher scholarship given to the author Fábio Luiz de Oliveira and for INCAPER, for the concession of climatic data.

\section{[References]}

[1] Abedinpour M, Sarangi A, Rajput T B S, Singh M, Pathak H, Ahmad T. Performance evaluation of AquaCrop model for maize crop in a semi-arid environment. Agric. Water Manag., 2012; 110: 55-66.

[2] Santos R A, Santos E P, Sales R A, Santos R L. Estimativa da evapotranspiração de referência para o município de Feira de Santana (BA) Revista Brasileira de Agricultura Irrigada, 2017; 11(4): 1617-1626. (in Brazilian)

[3] Sales R A, Louzada J M, Oliveira E C, Pinheiro M A B, Sales R A. Estimativa das necessidades hídricas do milho cultivado nas condições edafoclimáticas de São Mateus - ES. Enciclopédia Biosfera, 2016; 13(23): 598-609. (in Brazilian)

[4] Oliveira E C D, Costa J M N, Paula Júnior T J, Ferreira W P M, Justino F $\mathrm{B}$, Neves L D O. The performance of the CROPGRO model for bean (Phaseolus vulgaris L.) yield simulation. Acta Sci. Agron., 2012; 34(3): 239-246.

[5] Darko R O, Shouqi Y, Haofang Y, Liu J, Abbey A. Calibration and validation of AquaCrop for deficit and full irrigation of tomato. Int. J. Agric. \& Biol. Eng., 2016; 9(3): 104-110.

[6] Mirsafi Z S, Sepaskhah A R, Ahmadi S H, Kamgar-Haghighi A A. Assessment of AquaCrop model for simulating growth and yield of saffron (Crocus sativus L.). Sci. Hortic., 2016; 211: 343-351.

[7] Rinaldi M, Garofalo P, Rubino P, Steduto P. Processing tomatoes under different irrigation regimes in Southern Italy: agronomic and economic assessments in a simulation case study. Ital. J. of Agrometeorology, 2011; 3(3): 39-56

[8] Suárez-Rey E M, Romero-Gámez M, Giménez C, Thompson R B, Gallardo M. Use of EU-Rotate_N and CropSyst models to predict yield, growth and water and $\mathrm{N}$ dynamics of fertigated leafy vegetables in a Mediterranean climate and to determine $\mathrm{N}$ fertilizer requirements. Agricultural Systems, 2016; 149: 150-164.

[9] Ávila M R, Barizão D A O, Gomes E P, Fedri G, Albrecht L P. Fall/winter bean crop loam in association with biostimulant application and foliar fertilizer in both presence and absence of irrigation. Sci. Agrar., 2010; 11(3): 221-230.

[10] Sales R A, Ambrozim C S, Posse R P, Oliveira E, Posse S P. Satisfaction index of water and productivity demands on beans on different irrigation depths in Colatina - ES. Revista Energia na Agricultura, 2017; 32(1): 81-87.

[11] Trombetta A, Iacobellis V, Tarantino E, Gentile F. Calibration of the AquaCrop model for winter wheat using MODIS LAI images. Agric. Water Manag., 2016; 164: 304-316.

[12] Raes D, Steduto P, Hsiao T C, Fereres E. AquaCrop-The FAO crop model to simulate yield response to water: II. Main algorithms and software description. Agron. J., 2009; 101(3): 438-447.

[13] Steduto P, Hsiao T C, Raes D, Fereres E. AquaCrop-the FAO crop model to simulate yield response to water: I. Concepts and underlying principles. Agron. J., 2009; 101(3): 426-437.

[14] Patel N, Kumar P, Singh N. Performance evaluation of AquaCrop in simulating potato yield under varying water availability conditions. Indian Agricultural Research Institute, 2008; New Delhi-110012.

[15] Casa A, Ovando G, Bressanini L, Martínez J. Aquacrop model calibration in potato and its use to estimate yield variability under field conditions. Atmospheric and Climate Sciences, 2013; 3(3): 397-407.

[16] Montoya F, Camargo D, Ortega J F, Córcoles J I, Domínguez A. Evaluation of Aquacrop model for a potato crop under different irrigation conditions. Agric. Water Manag., 2016; 164: 267-280.

[17] Santana I, Cardoso M H. Raiz tuberosa de yacon (Smallanthus sonchifolius): potencialidade de cultivo, aspectos tecnológicos e nutricionais. Cienc. Rural, 2008; 38(3): 898-905. (in Brazilian)

[18] Fernández E C, Viehmannová I, Lachman J, Milella L. Yacon [Smallanthus sonchifolius (Poeppig \& Endlicher) H. Robinson]: a new crop in the Central Europe. Plant Soil Environ., 2006; 52(12): 564-570.

[19] Thornthwaite C W. An approach toward a rational classification of climate. Geographical Review, 1948; 38(1): 55-94.

[20] Embrapa. Sistema brasileiro de classificação de solos. 3rd ed. Rio de Janeiro: Embrapa Solos, 2013; 353p. (in Brazilian)

[21] Tomasella J, Pachepsky Y A, Crestana S, Rawls W J. Comparison of two approximation techiniques to develop pedotrasnfer functions for Brazilian soil. Soil Sci. Soc. Am. J., 2003; 67: 1085-1092.

[22] Araya A, Habtu S, Hadgu K M, Kebede A, Dejene T. Test of AquaCrop model in simulating biomass and yield of water deficient and irrigated 
barley (Hordeum vulgare). Agric. Water Manag., 2010; 97(11): 1838-1846.

[23] Vanuytrecht E, Raes D, Steduto P, Hsiao T C, Fereres E, Heng L K, et al. AquaCrop: FAO's crop water productivity and yield response model. Environ. Model. Softw., 2014; 62: 351-360.

[24] Hsiao T C, Heng L, Steduto P, Rojas-Lara B, Raes D, Fereres E. AquaCrop - the FAO crop model to simulate yield response to water: III. Parameterization and testing for maize. Agron. J., 2009; 101(3): 448-459.

[25] Raes D, Steduto P, Hsiao T C, Fereres E. AquaCrop Reference Manual AquaCrop Version 4.0, 2012. http://www.fao.org/nr/water/aquacrop.html.

[26] Willmott C J, Ckleson S G, Davis R E. Statistics for evaluations and comparisons of models. Journal of Geophysical, 1985; 90(C5): 8995-9005.

[27] R Core Team. R: A language and environment for statistical computing. $\mathrm{R}$ Foundation for Statistical Computing, Vienna, Austria. 2016. https://www.R-project.org/.

[28] Struik P C. Responses of the potato plant to temperature, in Potato Biology and Biotechnology. Elsevier Science BV, 2007; pp.367-393.
[29] Quiroz R. Potato. In: Steduto P, Hsiao T C, Fereres E, Raes D. (Eds.), Crop Yield Response to Water. Irrigation and Drainage Paper 66. Roma: FAO, 2012; pp.184-191.

[30] Hanks R J. Yield and water-use relationships: an overview. In: Taylor H M, Jordan W R, Sinclair T R. (Eds.), Limitations to Efficient Water Use in Crop Production. ASA, CSSA, and SSSA, Madison, WI, USA, 1983; pp. 393-411.

[31] Struik P C, Ewing E E. Crop physiology of potato (Solanum tuberosum): responses to photoperiod and temperature relevant to crop modelling. In: Haverkort A J, Mackerron D K L (Eds.), Potato Ecology and Modelling of Crops under Conditions Limiting Growth. Kluwer Academic Publishers, Dordrecht, The Netherlands, 1995; pp.19-41.

[32] Paula F L M, Streck N A, Heldwein A B, Bisognin D A, Paula A L D, Dellai J. Thermal time of some developmental phases in potato (Solanum tuberosum L.). Cienc. Rural, 2005; 35(5): 1034-1042.

[33] Farahani H J, Izzi G, Oweis T Y. Parameterization and evaluation of the AquaCrop model for full and deficit irrigated cotton. Agron. J., 2009; 101(3): 469-476. 